\title{
Genetic Diversity in Jatropha platyphylla Accessions Based on Morphological Traits and Inter-Simple Sequence Repeats Molecular Markers
}

\author{
Edith Salazar-Villa1, Lilia Alcaraz-Meléndez², Josefina León-Félix ${ }^{1}$, José Basilio Heredia1, \\ Federico Soto-Landeros ${ }^{3}$, Veronica Pérez-Rubio', Eduardo Sánchez-Valdez' \\ Miguel Angulo Angulo-Escalante ${ }^{*}$
}

\author{
${ }^{1}$ Centro de Investigación en Alimentación y Desarrollo, A.C. (CIAD), Coordinación Culiacán, Sinaloa, México \\ ${ }^{2}$ Centro de Investigaciones Biológicas del Noroeste, S.C (CIBNOR), La Paz, Baja California Sur, México \\ ${ }^{3}$ Instituto Tecnológico Superior de Guasave, Guasave, Sinaloa, México \\ Email: ^mangulo@ciad.mx
}

How to cite this paper: Salazar-Villa, E., Alcaraz-Meléndez, L., León-Félix, J., Heredia, J.B., Soto-Landeros, F., Pérez-Rubio, V., Sánchez-Valdez, E. and Angulo-Escalante, M.A. (2021) Genetic Diversity in Jatropha platyphylla Accessions Based on Morphological Traits and Inter-Simple Sequence Repeats Molecular Markers. American Journal of Plant Sciences, 12, 1658-1672. https://doi.org/10.4236/ajps.2021.1211116

Received: September 30, 2021

Accepted: November 20, 2021

Published: November 23, 2021

Copyright $\odot 2021$ by author(s) and Scientific Research Publishing Inc. This work is licensed under the Creative Commons Attribution International License (CC BY 4.0).

http://creativecommons.org/licenses/by/4.0/ (c) (i) Open Access

\begin{abstract}
Seven accessions of Jatropha platyphylla were evaluated for their phenotypic traits and genetic diversity using inter-simple sequence repeats (ISSRs). Cluster analyses with nine traits were performed: number of branches per plant; fruit per bunch; bunch per branch; bunch per plant; total seed production; total fruit production, protein content, oil content, and fatty acid profile. Genotypes from Rosario, Sinaloa, Mexico (PR11) yielded the highest values in all traits. The correlation analysis of the quantitative traits showed high correlations between seed and total fruit production $(\mathrm{r}=0.99)$. Unsaturated linoleic acid was the most abundant fatty acid (57.64\% - 52.39\%). Within a genetic improvement program, two of the most important variables to be considered are oil content and phenotypic characteristics of the plant. J. platyphylla has shown viable selection traits that provide a possibility of producing interspecies hybrids and giving them added value. ISSRs primers generated variable banding patterns that were found to be polymorphic; the polymorphic information content (PIC) of these loci ranged from 0.21 to 0.45 with an average of 0.34 . The unweighted pair group method (UPGMA) cluster analysis of the data showed the formation of three groups, where the most divergent accession pair was the genotype from Quelite (QP11) and Rosario (PR11).
\end{abstract}

\section{Keywords}

Fatty Acids, Oil, Molecular Markers, Polymorphism, Plant Breeding 


\section{Introduction}

Jatropha platyphylla is a non-toxic wild plant in Mexico that promises to be an alternative in oil and protein production for energy and food purposes [1]. Little is known about this species, such as its geographical distribution in the low deciduous forest, close to the Mexican Pacific coast [2]. The kernel seed of J. platyphylla has high oil content (60\%), and the oil extraction residue cake contains $75 \%$ crude protein, which does not contain phorbol esters known as the responsible compounds for J. curcas toxicity [3]. Despite this potential, J. platyphylla is a wild plant that has not been domesticated so far. Intensive human intervention for the domestication of the plant is necessary to make the crop profitable [4]. Therefore, the establishment of crops that meet the needs of stable and commercial cultivars with high oil content and tolerance to pests and diseases requires developing a genetic improvement program [5]. However, lack of information exists on molecular characterization of this plant, which makes the determination of genetic variability essential for this program. Molecular markers constitute an important technological tool useful in the selection and increase of the genetic variability process, especially when they are associated with phenotypic population analysis [6].

Among available and widely used methods to characterize genetic diversity, the Inter-Simple Sequence Repeat (ISSR) molecular marker technique offers unique advantages over other molecular markers since its application does not require prior genomic information of the species under study, except for only a small amount of template DNA, which is quickly performed [7]. The ISSR technique has been used to identify the relationship between species of Jatropha from different locations around the world [8]. Different levels of genetic diversity have been found. In America, high variability has been found [9] in comparison with accessions from Brazil [10], Taiwan, China [11], Africa and Asia [12] that have shown low diversity. Previous studies conducted on Jatropha curcas showed that the ISSR analysis allowed to identify the genetic diversity in the wild germplasm of the different regions of Sinaloa, these researchers conclude that this analysis is important in the selection of plants and the establishment of potential crops for the production of biodiesel, as well as the possibility of improving and identifying new varieties [13]. Therefore, the aim of this study was to evaluate the phenotypic traits and genetic diversity of J. platyphylla accessions by molecular markers and ISSR to identify genotypes that could be utilized in the breeding programs.

\section{Material and Methods}

\subsection{Plant Material}

The J. platyphylla representative collection was classified into seven accessions based on their different geographical regions of origin and morphological and distinguishing features (Table 1). The cuttings were disinfected (Blindaje 50 ${ }^{1}$ Genetic Diversity in Jatropha platyphylla by ISSR. 
Table 1. Sampling sites and major characteristics of Jatropha platyphylla genotypes in Mexico.

\begin{tabular}{|c|c|c|c|c|c|}
\hline Accession & $\begin{array}{l}\text { Collection } \\
\text { area }\end{array}$ & $\begin{array}{l}\text { Latitude } \\
\qquad(\mathrm{N})\end{array}$ & $\begin{array}{l}\text { Longitude } \\
\text { (W) }\end{array}$ & $\begin{array}{l}\text { Altitude } \\
\text { (masl) }\end{array}$ & $\begin{array}{c}\text { Plant } \\
\text { characteristics }\end{array}$ \\
\hline LH3 & $\begin{array}{l}\text { Higuerita, } \\
\text { Sinaloa }\end{array}$ & $24^{\circ} 45^{\prime} 37.6^{\prime \prime}$ & $107^{\circ} 08^{\prime} 39.1^{\prime \prime}$ & 200 & $\begin{array}{l}\text { High } \\
\text { oil content }\end{array}$ \\
\hline PP1 & $\begin{array}{l}\text { Mocorito, } \\
\text { Sinaloa }\end{array}$ & $25^{\circ} 04^{\prime} 11.4^{\prime \prime}$ & $107^{\circ} 43^{\prime} 10.7^{\prime \prime}$ & 51 & $\begin{array}{c}\text { Monoecious } \\
\text { plants }\end{array}$ \\
\hline PP3 & $\begin{array}{l}\text { Mocorito, } \\
\text { Sinaloa }\end{array}$ & $25^{\circ} 04^{\prime} 11.4^{\prime \prime}$ & $107^{\circ} 43^{\prime} 10.7^{\prime \prime}$ & 51 & $\begin{array}{c}\text { Most } \\
\text { branched }\end{array}$ \\
\hline PR11 & $\begin{array}{l}\text { Rosario, } \\
\text { Sinaloa }\end{array}$ & $23^{\circ} 11^{\prime} 18.5^{\prime \prime}$ & $106^{\circ} 09^{\prime} 09.3^{\prime \prime}$ & 15 & $\begin{array}{l}\text { High } \\
\text { oil content }\end{array}$ \\
\hline QP11 & $\begin{array}{l}\text { Quelite, } \\
\text { Sinaloa }\end{array}$ & $23^{\circ} 31^{\prime} 51.3^{\prime \prime}$ & $106^{\circ} 30^{\prime} 10.8^{\prime \prime}$ & 58 & $\begin{array}{l}\text { High } \\
\text { oil content }\end{array}$ \\
\hline QP6 & $\begin{array}{l}\text { Quelite, } \\
\text { Sinaloa }\end{array}$ & $23^{\circ} 31^{\prime} 51.3^{\prime \prime}$ & $106^{\circ} 30^{\prime} 10.8^{\prime \prime}$ & 58 & $\begin{array}{l}\text { High } \\
\text { oil content }\end{array}$ \\
\hline TP3 & $\begin{array}{l}\text { Tamazula, } \\
\text { Durango }\end{array}$ & $24^{\circ} 59^{\prime} 12.2^{\prime \prime}$ & $106^{\circ} 59^{\prime} 17.8^{\prime \prime}$ & 263 & $\begin{array}{l}\text { High } \\
\text { oil content }\end{array}$ \\
\hline
\end{tabular}

ArystaLifeScience ${ }^{\mathrm{TM}}$, Mexico; $\left.0.5 \mathrm{~g} \cdot \mathrm{L}\right)$ and kept in rooted solution for $24 \mathrm{~h}$ (Rooting Agroenzymas ${ }^{\mathrm{TM}}$, Mexico, $200 \mathrm{mg} \cdot \mathrm{L}$ ). Subsequently, rooted cuttings were planted in plastic bags $(20 \times 10 \mathrm{~cm})$ with substrate [sand $(40 \%)$, coconut fiber (30\%) and vermicompost (30\%)]. Three months later (July 2017), they were transferred on an experimental plot at "La Campana", Culiacán, Sinaloa, Mexico (N $\left.24^{\circ} 59^{\prime} 29.0^{\prime \prime}, \mathrm{W} 107^{\circ} 34^{\prime} 25.1^{\prime \prime}\right)$ in a completely randomized block design with a distance of $3 \times 3 \mathrm{~m}$. The plants received integrated management for pest control and fertilization with nitrogen, phosphorus, and potassium (NPK17-17-17; Innovacionagricola, Mexico), compost, drip irrigation, and pruning. The plot contained sandy loamy soils with $\mathrm{pH}$ of 7.2. Daily environmental conditions (temperature, relative humidity, precipitation) were recorded at an automated station of the brand AdcomTelemetry ${ }^{\mathrm{TM}}$ (Klosterneuburg, AT) located on the study site.

\subsection{Phenotypic Trait Characterization}

The variation observed in nine quantitative traits viz., number of branches per plant (BP); fruit per bunch (FI); bunches per branch (NI); bunches per plant $(\mathrm{NF})$; total seed production (SWP); total fruit production (PFP), protein content (P \%), oil content (O \%) and fatty acid profile (FAP) [14] [15] was recorded on two-year-old plants.

The fatty acid content was performed by extraction, separation, methylation, purification, and quantification according to Folch method [16] [17].

\subsection{ISSR and Data Analysis}

According to the CTAB protocol with minor modifications [18], the total genomic DNA was extracted from the youngest leaves of three plants of each $J$. 
platyphylla accession. ISSR 841, 836, 880, and 827 primers were used (UBC Num. 9, University of British Columbia, CAN). The polymerase chain reaction (PCR) mixture consisted of 50 ng DNA, $25 \mu \mathrm{L}$ Amplitaq Gold 360 Master Mix (Applied Biosystems ${ }^{\mathrm{TM}}$; USA) and ultrapure distilled water. DNA amplification was performed by PCR in a Biorad Thermal Cycler (Biorad ${ }^{\mathrm{TM}}$, USA) with an initial denaturation at $95^{\circ} \mathrm{C}$ for $10 \mathrm{~min}$ followed by 39 cycles at $92^{\circ} \mathrm{C}, 1 \mathrm{~min}$ annealing temperature (Ta), 2 min elongation at $72^{\circ} \mathrm{C}$ and final extension at $72^{\circ} \mathrm{C}$ for $7 \mathrm{~min}$. PCR products were subjected to $1.5 \%$ agarose gel electrophoresis in tris-acetate-EDTA (TAE) buffer and stained with ethidium bromide at $70 \mathrm{~V}, 200$ $\mathrm{mA}$ for $1 \mathrm{~h}$. A gel was photographed on ultraviolet (UV) light Axygen ${ }^{\circledR}$ Gel Documentation System (Corning ${ }^{\mathrm{TM}}$, USA).

A binary matrix (absence $=0$ and presence of the marker $=1$ ) was created from digitized banding profile of agarose gels using the software Image Lab (Biorad $^{\mathrm{TM}}$, USA). Two replications were performed per accession. Blurred bands were discarded. This matrix was used to calculate the similarity between the accessions using the Dice and Jaccard Index. Afterwards, the accessions were grouped according to UPGMA, using the software PAST v.3.17 [19]. The Polymorphism Information Content (PIC) value was calculated in accordance with Tanya et al. [20]. The number of bands and polymorphic markers and polymorphism percentage were calculated. Primers ISSRs that had a minimum PIC value of 0.3 was set aside for analysis.

Phenotypic traits were evaluated using descriptive statistics to know the mean, standard deviation, maximum and minimum values and the coefficient of variation. An analysis of variance (ANOVA p $<0.05$ ) was performed to find significant differences between genotypes for mean comparison followed by Fisher's post hoc tests and subjected to Principal Components Analysis (PCA). In addition, a correlation analysis was performed between phenotypic traits used with MINITAB 17.

\section{Results and Discussion}

\subsection{Environmental Conditions and Phenotypic Traits}

Soil $\mathrm{pH}$ of the crop was 7.2, and soil type in this area was not limited for the good development of the plantations. Jatropha adapts to a wide variety of soils, including those with low nutrient content although it prefers light and well-drained soils. Mixed clay and sandy soils provide a texture that promotes better aeration, facilitates gas exchange, and increases photosynthetic activity [21]. It usually develops in arid and semi-arid soils and responds well to a wide range of $\mathrm{pH}$ levels although it prefers them slightly acidic [22].

Relative humidity data showed an average of $75 \% \pm 5 \%$. The monthly average of maximum temperature ranged from $25.5^{\circ} \mathrm{C}-38.9^{\circ} \mathrm{C}$ and minimum from $10.2^{\circ} \mathrm{C}-25^{\circ} \mathrm{C}$. The mean temperature from December to January was $19.1^{\circ} \mathrm{C}$, while the minimum mean temperature was $4.9^{\circ} \mathrm{C}$; the maximum temperature from April to February was around $31.7^{\circ} \mathrm{C}$. Two rain peaks were recorded, one 
from June to August and another one from October to December, which was scanty. Overall, the mean annual precipitation ranged approximately $570 \mathrm{~mm}$. The accumulated annual precipitation of the area was below the optimum level established for the Jatropha crop, which requires from 800 to $1500 \mathrm{~mm}$ [23]; hence, it was necessary to complement water requirements with assisted irrigation. The reported temperature for J. platyphylla includes temperatures from $29^{\circ} \mathrm{C}$ to $34.0^{\circ} \mathrm{C}$ [23]. The maximum average temperature at the study site was $32.2^{\circ} \mathrm{C}$. The annual minimum relative humidity was $55 \%$, while the annual maximum was $79 \%$. At this relative humidity, the area was assumed to be in the optimal range for crop establishment and should be supported by irrigation during the driest months (April to June) to reduce the vapor pressure deficit. Climate factors had significant effects on distribution, productivity, seed yield and oil content of genotypes [1]. The most important factors for the superiority of genotypes in terms of seed yield include annual temperature and precipitation and soil parameters, which affect the availability of water and nutrients to plants.

A significant variation was observed in all the phenotypic traits recorded $(\mathrm{p}<$ 0.05 ) (Table 2). The phenotypic variation indicated the existence of diversity for all traits. Phenotypic traits are important characteristics for genotype selection; in addition, genetic variability is important to consider because environmental effects can cause high variation to distinguish effectively between genotypes [24].

Table 2. Results of statistical analyses of phenotypic traits and oil and protein content of Jatropha platyphylla genotypes.

\begin{tabular}{ccccccccc}
\hline Accession & BP & FI & NI & NF & SWP & PFP & O \% & P \% \\
\hline LH3 & $1.50^{\mathrm{b} *}$ & $2.66^{\mathrm{d}}$ & $1.50^{\mathrm{bc}}$ & $2.33^{\mathrm{bc}}$ & $65.00^{\mathrm{b}}$ & $124.20^{\mathrm{b}}$ & $60.23^{\mathrm{a}}$ & $22.36^{\mathrm{d}}$ \\
PP1 & $1.63^{\mathrm{b}}$ & $1.54^{\mathrm{e}}$ & $1.00^{\mathrm{d}}$ & $1.81^{\mathrm{c}}$ & $43.64^{\mathrm{b}}$ & $81.80^{\mathrm{b}}$ & $54.59^{\mathrm{c}}$ & $26.79^{\mathrm{a}}$ \\
PP3 & $2.50^{\mathrm{ab}}$ & $1.00^{\mathrm{e}}$ & $1.00^{\mathrm{cd}}$ & $2.00^{\mathrm{bc}}$ & $85.00^{\mathrm{b}}$ & $153.80^{\mathrm{b}}$ & $60.47^{\mathrm{a}}$ & $25.73^{\mathrm{b}}$ \\
PR11 & $2.58^{\mathrm{a}}$ & $6.83^{\mathrm{a}}$ & $2.33^{\mathrm{a}}$ & $7.75^{\mathrm{a}}$ & $204.20^{\mathrm{a}}$ & $336.30^{\mathrm{a}}$ & $59.15^{\mathrm{ab}}$ & $27.29^{\mathrm{a}}$ \\
QP11 & $2.42^{\mathrm{ab}}$ & $3.14^{\mathrm{cd}}$ & $1.87^{\mathrm{b}}$ & $3.57^{\mathrm{b}}$ & $59.60^{\mathrm{b}}$ & $110.10^{\mathrm{b}}$ & $59.90^{\mathrm{a}}$ & $24.33^{\mathrm{c}}$ \\
QP6 & $1.0^{\mathrm{b}}$ & $4.00^{\mathrm{c}}$ & $1.33^{\mathrm{cd}}$ & $1.33^{\mathrm{c}}$ & $35.83^{\mathrm{b}}$ & $69.17^{\mathrm{b}}$ & $59.43^{\mathrm{ab}}$ & $25.64^{\mathrm{b}}$ \\
TP3 & $1.87^{\mathrm{ab}}$ & $5.37^{\mathrm{b}}$ & $1.50^{\mathrm{bc}}$ & $3.37^{\mathrm{b}}$ & $34.00^{\mathrm{b}}$ & $78.30^{\mathrm{b}}$ & $57.71^{\mathrm{b}}$ & $22.67^{\mathrm{d}}$ \\
Mean & 2.01 & 3.85 & 1.57 & 3.61 & 150.1 & 84.5 & 58.78 & 24.97 \\
Minimum & 1.00 & 1.00 & 1.00 & 1.00 & 20.00 & 10.00 & 52.60 & 22.04 \\
Maximum & 5.00 & 8.00 & 3.00 & 13.00 & 605.00 & 360.00 & 61.25 & 28.19 \\
SD & 0.94 & 2.28 & 0.63 & 2.81 & 139.3 & 86.9 & 2.17 & 1.87 \\
CV & 46.64 & 59.33 & 40.18 & 77.85 & 92.81 & 102.87 & 3.69 & 7.50 \\
\hline
\end{tabular}

Number of branches per plant (BP); fruit per bunch (FI); bunch per branch (NI); bunch per plant (NF); total seed production (SWP) (g); total fruit production (PFP) (g); protein content (\% P) (\%); and oil content (\% O) (\%). CV: coefficient of variation (\%), SD: standard deviation. ${ }^{\star}$ Different letters within a row indicate significant differences $\mathrm{p}<0.05$. 
Knowing the relationship between genotypes under specific environmental and soil conditions is valuable for improving growth and promoting seed and oil yields [25].

The highest values were number of branches per plant (BP) (2.58); fruit per bunch (FI) (6.83); bunch per branch (NI) (2.33); bunch per plant (NF) (7.75); total seed production (SWP) (204.20 g); total fruit production (PFP) (336.30 g), protein content (P \%) (60.23\% and 59.90\%), and oil content (O \%) $(27.29 \%$ and 26.79\%). PR11 genotype yielded the highest values of BP, FI, NI, NF, SWP, PFP and P \%, while the LH3 and QP11 genotypes yielded the highest oil content $(\mathrm{O} \%)$ values. $\mathrm{PP} 1$ yielded the highest value of protein content $(\mathrm{P} \%)$, similar to PR11. BP, FI, NI, NF, SWP and PFP, showed high CVs (>20\%). Oil (O \%) and protein content $(\mathrm{P} \%)$ had low coefficient of variation (CV) $(<10 \%)$ (Table 2$)$. The populations evaluated in this study had sufficient variability for genotype selection of superior agronomic performance [26]. This fact is important for the establishment of a genetic improvement program. The coefficients of variation (CV) showed the variability between accessions. The phenotypic differences suggested genetic variation and/or variation in response to different environmental conditions, since the influence of the genotype and the environment on phenotypic variation may occur simultaneously [27]. The high endemism found in Mexico could be responsible for the high variability between genotypes [28].

The quantitative trait correlation analysis showed high correlations between SWP and PFP $(r=0.99)$. The traits that showed moderate correlation were BP with NF $(r=0.42)$; FI with NI $(r=0.64)$, NF $(r=0.63)$, PFP (0.49), SWP $(r=$ $0.48)$ and $\mathrm{O} \%(0.57)$; NI with NF $(\mathrm{r}=0.61)$, PFP $(\mathrm{r}=0.44)$, SWP $(\mathrm{r}=0.43)$ and $\mathrm{O} \%(0.44)$; NF with PFP $(\mathrm{r}=0.65)$ and SWP $(\mathrm{r}=0.66)$. PFP with $\mathrm{P} \%(\mathrm{r}=0.35)$; $\mathrm{O} \%$ with $\mathrm{P} \%(\mathrm{r}=-0.49)$. Low correlations were observed between $\mathrm{BP}$ and $\mathrm{NI}(\mathrm{r}$ $=0.23)$, PFP $(r=0.28)$ and SWP $(r=0.30)($ Table 3$)$.

Table 3. Correlation coefficient (r) values of the phenotypic characteristics and oil and protein contents of Jatropha platyphylla genotypes. Number of branches per plant (BP); fruit per bunch (FI); bunch per branch (NI); bunch per plant (NF); total seed production (SWP) (g); total fruit production (PFP) (g); protein content (\% P) (\%); and oil content (\% O) $(\%) \cdot{ }^{*} \mathrm{p} \leq 0.05$.

\begin{tabular}{|c|c|c|c|c|c|c|c|}
\hline & $\mathrm{BP}$ & FI & NI & $\mathrm{NF}$ & PFP & SWP & O \% \\
\hline FI & 0.15 & & & & & & \\
\hline NI & $0.23^{*}$ & $0.64^{\star}$ & & & & & \\
\hline NF & $0.42^{*}$ & $0.63^{*}$ & $0.61^{\star}$ & & & & \\
\hline PFP & $0.28^{\star}$ & $0.49^{\star}$ & $0.44^{\star}$ & $0.65^{\star}$ & & & \\
\hline SWP & $0.30^{*}$ & $0.48^{\star}$ & $0.43^{\star}$ & $0.66^{\star}$ & $0.99^{*}$ & & \\
\hline O \% & 0.06 & $0.57^{\star}$ & $0.44^{*}$ & 0.25 & 0.08 & 0.08 & \\
\hline P \% & 0.02 & -0.08 & 0.05 & 0.20 & $0.35^{\star}$ & $0.36^{*}$ & $-0.49^{*}$ \\
\hline
\end{tabular}


The correlation coefficient for seed traits is shown in Table 4. All correlations were significant. KW: kernel weight (KW) had a high and significant correlation with seed weight (SW) and seed diameter (SD) ( $\mathrm{r}=0.95$ and 0.97).

The highest direct effect on SWP was obtained by PFP (0.99), which is an estimate close to the phenotypic correlation (Table 3). Thus, SWP is the main determinant in the variation of PFP and evidences the cause and effect relationship between these traits, i.e., the higher the fruit production is, and the higher the seed production is. The identification of traits that have high phenotypic correlation and high direct effect in the same direction on the main trait is desirable, since the correlated response by means of indirect selection can be effective [29]. The selection of genotypes with higher fruit and seed production aiming to increase oil or protein yield is a promising strategy because of the cause and effect relationship between these traits, as evidenced in this study. The negative correlation between seed protein and oil contents has been documented in other crops, such as soybean and castor bean [30] [31] [32]. Current evidence indicates that seed storage protein and oil are synthesized during seed development, following stored-starch break-down [31]. Seed protein and oil content are both complex quantitative traits, controlled by multiple genes and affected by environmental factors.

In this study the principal component analysis (PCA) showed significant differences in all traits evaluated. The first three components accounted for $81.5 \%$ of the total variation. PC1 accounted for $47.1 \%$ of the variability, PC2 for $22 \%$, and PC3 for $11 \%$. The first factor had high contributing factor loadings from FI, NI, NF, PFP and SWP. The second factor had high negative contributing loadings from $\mathrm{O} \%$ and positive loading in $\mathrm{P} \%$. The third factor had high negative contributing loadings from BP (Table 5). The graphical biplot interpretation of PC1 and PC2 revealed that the accessions showed differences in a set of eight traits (Figure 1).

The most divergent accession pair was QP11 and PR11 (Figure 2). The highest similarity was observed between QP11 and LH3. The branching patterns in the dendrogram resulted in three major groups. Group I was formed by QP11, LH3, and PP3; group II by QP6, TP3, and PP1; and group III by PR11.

Fatty acid profile (FAP) was similar for the genotypes although concentration of individual fatty acids differed significantly $(\mathrm{p}<0.05)$ (Table 6). The most

Table 4. Correlation coefficient (r) values of the phenotypic characteristics of Jatropha platyphylla genotypes. SW: Seed weight (g); SL: Seed longitude (mm); SD: Seed diameter (mm); TW: Shell weight (g); KW: Kernel weight (g). ${ }^{*} \mathrm{p} \leq 0.05$.

\begin{tabular}{ccccc}
\hline & SW & SD & TW & SL \\
\hline SD & $0.44^{*}$ & & & \\
TW & $0.85^{*}$ & $0.46^{\star}$ & & \\
SL & $0.89^{*}$ & $0.48^{*}$ & $0.78^{*}$ & \\
KW & $0.95^{*}$ & $0.97^{*}$ & $0.66^{*}$ & $0.71^{\star}$ \\
\hline
\end{tabular}


Table 5. Eigenvalues of the first three principal components of Jatropha platyphylla germplasm. PC1: First principal component, PC2: second principal component, PC3: third principal component. Number of branches per plant (BP); fruit per bunch (FI); bunch per branch (NI); bunch per plant (NF); total seed production (SWP) (g); total fruit production (PFP) (g); protein content (\% P) (\%); and oil content (\% O) (\%).

\begin{tabular}{cccc}
\hline Variable & PC1 & PC2 & PC3 \\
\hline BP & 0.22 & 0.055 & -0.92 \\
FI & 0.40 & -0.29 & 0.21 \\
NI & 0.38 & -0.20 & 0.10 \\
NF & 0.44 & 0.02 & 0.11 \\
PFP & 0.44 & 0.25 & 0.11 \\
SWP & 0.44 & 0.26 & 0.09 \\
O \% & 0.19 & -0.60 & 0.07 \\
P \% & 0.11 & 0.60 & 0.21 \\
Eigen value & 3.76 & 1.83 & 0.91 \\
Proportion & 0.47 & 0.22 & 0.11 \\
Cumulative & 47.1 & 70.1 & 81.5
\end{tabular}

Table 6. Fatty acid composition (\%) of Jatropha platyphylla. Means in a row followed by the same letter are not significantly different by Fisher's post hoc tests at the $5 \%$ level. SFA, UFA, MUFA, PUFA denote saturated, unsaturated, monounsaturated and polyunsaturated fatty acids, respectively.

\begin{tabular}{cccccccc}
\hline Fatty acid & LH3 & PP1 & PP3 & PR11 & QP11 & QP6 & TP3 \\
\hline Myristic C14:0 & $0.23^{\mathrm{ab}}$ & $0.17^{\mathrm{b}}$ & $0.23^{\mathrm{ab}}$ & $0.30^{\mathrm{ab}}$ & $0.36^{\mathrm{a}}$ & $0.35^{\mathrm{a}}$ & $0.19^{\mathrm{b}}$ \\
Palmitic C16:0 & $13.20^{\mathrm{bc}}$ & $14.16^{\mathrm{abc}}$ & $12.07^{\mathrm{c}}$ & $16.55^{\mathrm{a}}$ & $15.26^{\mathrm{ab}}$ & $14.31^{\mathrm{abc}}$ & $7.41^{\mathrm{d}}$ \\
Palmitoleic C16:1 & $0.45^{\mathrm{b}}$ & $0.44^{\mathrm{bc}}$ & $0.29^{\mathrm{e}}$ & $0.58^{\mathrm{a}}$ & $0.40^{\mathrm{cd}}$ & $0.37^{\mathrm{d}}$ & $0.40^{\mathrm{cd}}$ \\
Heptadecanoic C17:0 & $0.14^{\mathrm{abcd}}$ & $0.13^{\mathrm{bcd}}$ & $0.15^{\mathrm{abc}}$ & $0.11^{\mathrm{d}}$ & $0.16^{\mathrm{ab}}$ & $0.16^{\mathrm{ab}}$ & $0.12^{\mathrm{cd}}$ \\
Stearic C18:0 & $9.65^{\mathrm{a}}$ & $6.50^{\mathrm{cd}}$ & $9.38^{\mathrm{ab}}$ & $5.39^{\mathrm{d}}$ & $5.32^{\mathrm{d}}$ & $4.93^{\mathrm{d}}$ & $7.71^{\mathrm{bc}}$ \\
Oleic Cis 9 C18:1 & $21.44^{\mathrm{c}}$ & $26.18^{\mathrm{a}}$ & $24.76^{\mathrm{b}}$ & $23.52^{\mathrm{b}}$ & $23.38^{\mathrm{b}}$ & $23.60^{\mathrm{b}}$ & $26.07^{\mathrm{a}}$ \\
Linoleic C18:2 & $53.95^{\mathrm{bc}}$ & $52.39^{\mathrm{c}}$ & $53.79^{\mathrm{bc}}$ & $54.47^{\mathrm{b}}$ & $54.64^{\mathrm{b}}$ & $55.29^{\mathrm{b}}$ & $57.64^{\mathrm{a}}$ \\
Linolenic C18:3 & $0.10^{\mathrm{cd}}$ & $0.11^{\mathrm{bc}}$ & $0.12^{\mathrm{bc}}$ & $0.09^{\mathrm{d}}$ & $0.09^{\mathrm{d}}$ & $0.13^{\mathrm{ab}}$ & $0.15^{\mathrm{ab}}$ \\
Arachidic C20:0 & $0.10^{\mathrm{b}}$ & $0.15^{\mathrm{a}}$ & $0.09^{\mathrm{c}}$ & $0.10^{\mathrm{b}}$ & $0.10^{\mathrm{b}}$ & $0.10^{\mathrm{b}}$ & $0.15^{\mathrm{a}}$ \\
SFA & 24.51 & 21.20 & 21.25 & 20.31 & 21.22 & 20.62 & 17.20 \\
UFA & 75.55 & 79.30 & 78.62 & 79.68 & 78.77 & 79.27 & 82.79 \\
MUFA & 21.41 & 27.07 & 24.66 & 26.82 & 24.09 & 23.87 & 26.40 \\
PUFA & 54.13 & 51.78 & 54.10 & 52.85 & 54.67 & 55.28 & 56.38 \\
\hline
\end{tabular}



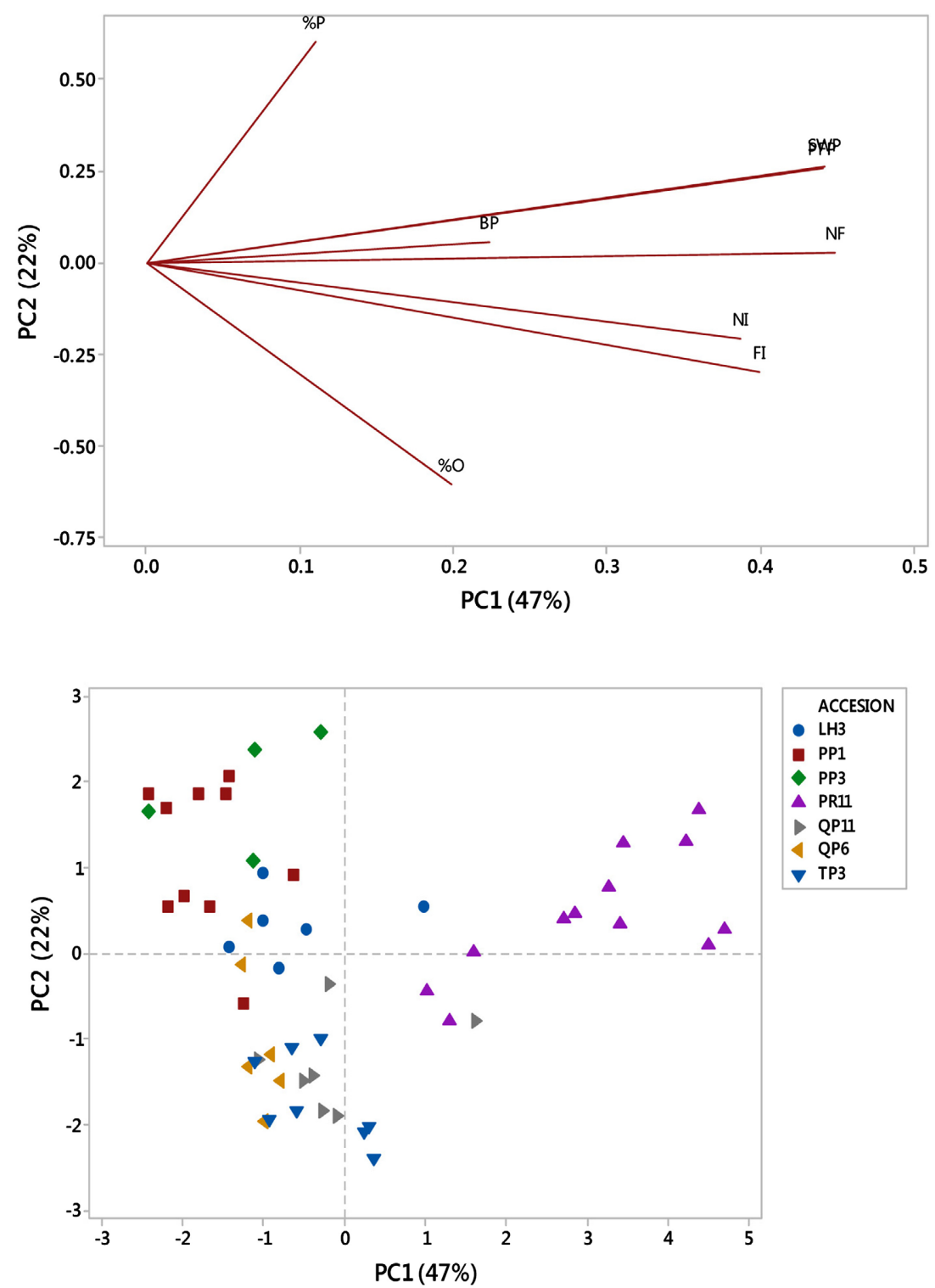

Figure 1. Loading and score plots of the principal component analysis (PCA) of Jatrophaplatyphylla. Number of branches per plant (BP); fruit per bunch (FI); bunch per branch (NI); bunch per plant (NF); total seed production (SWP) (g); total fruit production (PFP) (g); protein content (\% P) (\%); and oil content (\% O) (\%). PC1: first principal component, PC2: second principal component.

abundant fatty acids were the unsaturated linoleic $(57.64 \%-52.39 \%)$ and oleic $(26.07 \%-21.44 \%)$ acids, and the saturated palmitic $(16.55 \%-12.07 \%)$ and stearic $(9.65 \%-4.93 \%)$ acids. The composition of fatty acids plays an important role in selection of oils with fuel and nutritional potential. The fatty acid profile is dominated by palmitic and stearic saturated acid and linoleic and oleic unsaturated acids. Linoleic acid was the main fatty acid that may have potential as edible oil for the food industry [2]. In contrast, soybean, and J. curcas oils showed similar chemical profiles regarding main fatty acid content, mainly oleic acid [33] for biodiesel production. 


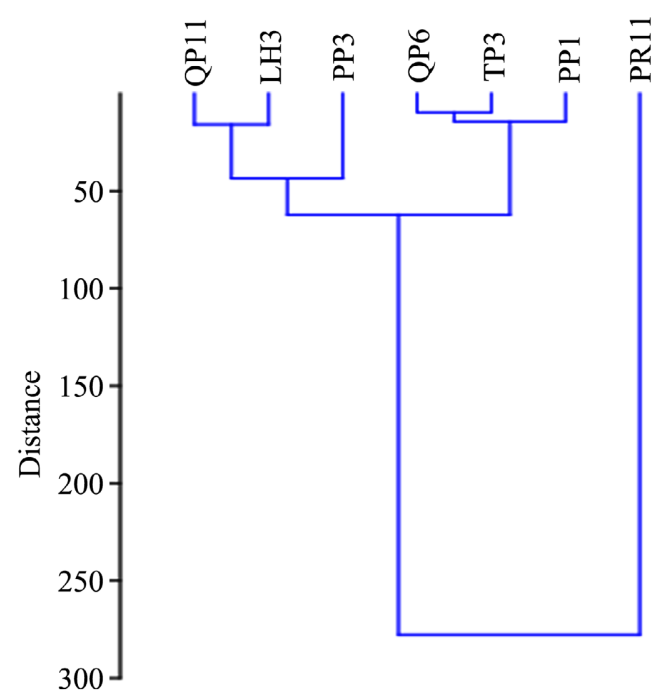

Figure 2. Dendrogram of Jatropha platyphylla genotypes based on the Jaccard index calculated from data of 122 ISSR loci, using the unweighted pair group method (UPGMA) as the clustering method. Groups are described in the results and discussion section. Table 1 shows the accession codes.

\subsection{ISSR Molecular Marker Diversity}

Determining the genetic variation between J. platyphylla accessions using phenotypic traits and molecular analysis is critical to choosing the parents that will cross paths to generate appropriate populations for breeding purposes [34]. The genetic diversity status of $J$. platyphylla has not been clear yet. Therefore, this study provided the first assessment of the genetic diversity of J. platyphylla accessions using ISSR markers. Despite the high genomic similarity, the profiles of the molecular markers show different patterns of amplification in the accessions. In this research the study pattern of specific alleles was observed whereby the population had specific amplification to its accessions.

The number of bands formed by different ISSR primers ranged from 5 to 8 with an average of 7 bands per primer. The maximum number of amplified product (8) was observed in the profiles of the primer UBC 827 and primer UBC 836. The minimum number of amplified product (5) was observed in the profiles of primer UBC 841. In the seven accessions, a total of 122 bands were obtained. Molecular weights ranged from 225.22 to $1500 \mathrm{bp}$. The percentage of polymorphic bands ranged between $40 \%$ and $100 \%$. PIC values were in a range from 0.21 to 0.45 , with a mean value 0.34 . ISSR primers 836 showed the lowest PIC value, while ISSR 880 showed the highest value (Table 7). The PIC value provides a measure influenced by the number and frequency of alleles. The maximum value of PIC for ISSR marker is 0.5 because of the presence of two alleles per locus [35] [36]. The PIC value reveals the informativeness level and accordingly defined into categories: low ( 0 to 0.10 ), medium ( 0.10 to 0.25 ), high ( 0.30 to 0.40$)$ and very high $(0.40$ to 0.50$)$ [37]. The moderate PIC values for the ISSR primers could have been attributed to the diverse nature of the accessions and/or highly informative ISSR markers used in this study [38]. 
Table 7. Genetic diversity parameters for Jatropha platyphylla genotypes.

\begin{tabular}{cccccc}
\hline $\begin{array}{c}\text { Primer } \\
\text { ISSR }\end{array}$ & Sequence & $\begin{array}{c}\text { Number } \\
\text { of bands }\end{array}$ & $\begin{array}{c}\text { Number of } \\
\text { polymorphic } \\
\text { markers }\end{array}$ & $\begin{array}{c}\text { \% of } \\
\text { polymorphism }\end{array}$ & $\begin{array}{c}\text { PIC } \\
\text { value }\end{array}$ \\
\hline UBC880 & GGAGAGGAGAGGAGA & 7 & 5 & 71.42 & 0.45 \\
UBC827 & ACACACACACACACACG & 8 & 8 & 100 & 0.36 \\
UBC836 & AGAGAGAGAGAGAGAGYA & 8 & 4 & 50 & 0.21 \\
UBC841 & GAGAGAGAGAGAGAGAYC & 5 & 2 & 40 & 0.34 \\
\hline
\end{tabular}

The generated mean Jaccard's coefficient of similarity was 0.53 . The maximum coefficient of similarity (0.76) was found between accessions PR11 and PP3. The lowest coefficient of similarity $(0.28)$ was found between accessions LH3 and QP11. Dice index was 0.72 . The maximum coefficient of similarity (0.86) was found between accessions PR11 and PP3. The lowest coefficient of similarity (0.43) was found between accessions LH3 and QP11.

Polymorphism and genetic information provided by ISSR technique can be complemented with information from phenotypic and biochemical characterization, and thus be able to elucidate in a clearer way the intricate relationships and interactions that occur in most materials to assess their intraspecific diversity on a much finer scale [39]. In plants of J. curcas, the genetic diversity of accessions has been evaluated in populations of India and Brazil [9] [10] [40], Taiwan [11], South America (Costa Rica) [41], Africa and Asia [42], Indonesia [43]. These studies have revealed a low diversity attributed to the origin of plant material via vegetative propagation, which increases the possibility that germplasm banks store plants of identical provenance [40].

The high diversity found in Mexican accessions of $J$. curcas agrees with this investigation [5] [13] [44], which may be because Mexico and Central American is considered the center of origin of the Jatropha genus [45] [46] and has a high endemism [28]. Polymorphism indicates that inter-simple sequence repeats are abundant and highly dispersed through the genome [47].

\section{Conclusion}

The results of this study can be considered a starting point for future research aimed at defining the level of genetic diversity to detect promising accessions to generate $J$. platyphylla hybrids. To achieve this purpose, a greater number of natural populations collected from the entire range should be analyzed and additional ISSR primers tested. In addition, discriminating bands should be cloned and sequenced. These studies have given important clues to understand the genotype-phenotype relationship, which can further help develop plant reproduction strategies.

\section{Acknowledgements}

The authors are grateful to Hector Carrillo, Jorge Luis Manjarrez, Alexander Ca- 
sian, Briceida Perez, and Werner Rubio for technical assistance. Special thanks to Rosa Fajardo, Evelyn Salazar and Diana Fischer for English editing.

\section{Conflicts of Interest}

The authors declare no conflicts of interest regarding the publication of this paper.

\section{References}

[1] Salazar-Villa, E., Alcaraz-Meléndez, L., León-Félix, J., Heredia, J.B., Soto-Landeros, F. amd Angulo-Escalante, M.A. (2020) Morphological Variability and Oil Content of Jatropha platyphylla Müll. Arg. Genotypes as Determined Using Multivariate Analysis. Scientia Horticulturae, 261, Article ID: 108968.

https://doi.org/10.1016/j.scienta.2019.108968

[2] Sosa-Segura, M., Oomah, B., Drover, J., Heredia, J., Osuna-Enciso, T., Valdez-Torres, J., Salazar-Villa, E., Soto-Landeros, F. and Angulo-Escalante, M. (2014) Physical and Chemical Characterization of Three Non-Toxic Oilseeds from the Jatropha Genus. Journal of Food and Nutrition Research, 2, 56-61.

[3] Makkar, H.P.S., Kumar, V., Oyeleye, O., Akinleye, A., Angulo-Escalante, M. and Becker, K. (2011) Jatropha platyphylla, a New Non-Toxic Jatropha Species: Physical Properties and Chemical Constituents Including Toxic and Antinutritional Factors of Seeds. Food Chemistry, 125, 63-71. https://doi.org/10.1016/j.foodchem.2010.08.037

[4] Salazar-Villa, E., Fajardo-Somera, R., Báez-Parra, K. and Soto Landeros, F. (2021) Genetic Data to Identify Jatropha Cultivars. In: Recent Studies on Jatropha Research, Nova Science Publishers, Inc., New York, 39-59.

[5] Díaz, B.G., Argollo, D.M., Franco, M.C., Nucci, S.M., Siqueira, W.J. and de Laat, D.M. (2017) High Genetic Diversity of Jatropha curcas Assessed by ISSR. Genetics and Molecular Research, 31, 1-13. https://doi.org/10.4238/gmr16029683

[6] Pazeto, M.S.R., Unêda-Trevisoli, S.H., Corrêa, A.A.P., Vianna, V.F., Leite, D.C. and Di Mauro, A.O. (2015) Genetic Diversity in Jatropha Species from Different Regions of Brazil Based on Phenotypic Characters and Inters-Simple Sequence Repeat (ISSR) Molecular Markers. African Journal of Biotechnology, 14, 2066-2079. https://doi.org/10.5897/AJB2014.14368

[7] Nasir, N.A., Anuar, N., Zainuddin, Z. and Yaakob, Z. (2017) Evaluation of Genetic Homogeneity of Jatropha curcas L. Hybrid at an Early Stage of Shoot Bud Formation from Petioles Using ISSR Marker. Biotechnology \& Biotechnological Equipment, 31, 45-50. https://doi.org/10.1080/13102818.2016.1257923

[8] Soonthornyatara, S., Sripichitt, P., Kaveeta, R. and Hongtrakul, V. (2015) Assessment of Genetic Diversity of Jatropha curcas L. Using AFLP and ISSR Markers. Warasan Khana Witthayasat Maha Witthayalai Chiang Mai, 42, 614-625.

[9] Mastan, S.G., Sudheer, P.D., Rahman, H., Ghosh, A., Rathore, M.S., Prakash, C.R. and Chikara, J. (2012) Molecular Characterization of Intra-Population Variability of Jatropha curcas L. Using DNA Based Molecular Markers. Molecular Biology Reports, 39, 4383-4390. https://doi.org/10.1007/s11033-011-1226-Z

[10] Grativol, C., da Fonseca Lira-Medeiros, C., Hemerly, A. and Ferreira, P.C. (2011) High Efficiency and Reliability of Inter-Simple Sequence Repeats (ISSR) Markers for Evaluation of Genetic Diversity in Brazilian Cultivated Jatropha curcas L. Accessions. Molecular Biology Reports, 38, 4245-4256. 
https://doi.org/10.1007/s11033-010-0547-7

[11] Mavuso Yong-Pei, W., Fure-Chyi, C., Bing-Hong, H. and Su-Ju, L. (2016) Genetic Diversity Analysis of Jatropha curcas L. Accessions Cultivated in Taiwan Using Inter Simple Sequence Repeats (ISSR) Markers. Agroforestry Systems, 90, 417-431. https://doi.org/10.1007/s10457-015-9864-0

[12] Trebbi, D., Eleni, G., Papazoglou, E., Massimo, V., Baldinid, P.S., Cettulf, E., Pia Sanzonef, A. and Gualdi, A.F. (2015) Assessment of Genetic Diversity in Different Accessions of Jatropha curcas. Industrial Crops and Products, 75, 35-39. https://doi.org/10.1016/j.indcrop.2015.06.051

[13] Araiza-Lizarde, N., Angulo-Escalante, M.A., Reynoso-Granados, T., Cruz-Hernández, P., Calderón-Vázquez, C. and Alcaraz-Melendez, L. (2021) Genetic Variability of Wild Jatropha curcas in Northwest Mexico. Tropical and Subtropical Agroecosystems, 24, 1-7.

[14] Sunil, N., Kumar, V., Rao, G. and Varaprasad, K. (2013) Minimal Descriptors for Characterization and Evaluation of Jatropha curcas L. Germoplasm for Utilization in Crop Improvement. Biomass Bioenergy, 48, 239-249.

https://doi.org/10.1016/j.biombioe.2012.11.008

[15] Sosa-Segura, M., Angulo-Escalante, M., Valdez-Torres, B., Osuna-Enciso, T., Allende-Molar, R. and Oomah, D. (2012) Phenology, Productivity and Chemical Characterization of Jatropha curcas L. as Tool for Selecting Non-Toxic Elite Germoplasm. African Journal of Biotechnology, 11, 15998-15993. https://doi.org/10.5897/AJB12.2556

[16] Folch, J., Lees, M. and Stanley, H. (1957) A Simple Method for the Isolation and Purification of Total Lipids from Animal Tissues. Journal of Biological Chemistry, 226, 497-509. https://doi.org/10.1016/S0021-9258(18)64849-5

[17] A.O.A.C. (1998) Official Methods of Analysis. 15th Edition, Association of Official Analytical Chemistry, Washington DC.

[18] Basha, S.D. and Sujatha, M. (2007) Inter and Intra-Population Variability of Jatropha curcas (L.) Characterized by RAPD and ISSR Markers and Development of Population-Specific SCAR Markers. Euphytica, 156, 375-386. https://doi.org/10.1007/s10681-007-9387-5

[19] Harper, D.A.T. and Ryan, P.D. (2001) PAST: Paleontological Statistics Software Package for Education and Data Analysis. http://palaeo-electronica.org/2001_1/past/issue1_01.htm

[20] Tanya, P., Taeprayoon, P., Hadkam, Y. and Srinives, P. (2011) Genetic Diversity among Jatropha and Jatropha-Related Species Based on ISSR Markers. Plant Molecular Biology Reporter, 29, 252-264. https://doi.org/10.1007/s11105-010-0220-2

[21] Sunil, N., Kumar, V. and Varaprasad, K.S. (2013) Origin, Domestication, Distribution and Diversity of Jatropha curcas L. In: Jatropha, Challenges for a New Energy Crop, Springer, New York, 137-151. https://doi.org/10.1007/978-1-4614-4915-7 9

[22] Montes, J.M. and Melchinger, A.E. (2016) Domestication and Breeding of Jatropha curcas L. Trends in Plant Science, 21, 1045-1057. https://doi.org/10.1016/j.tplants.2016.08.008

[23] Cordova-Téllez, L., Bautista-Ramírez, E., Zamarripa-Colmenero, A.A., Rivera-Lorca, J., Arturo, P.V., Sánchez, O. and Herrera, J. (2015) Diagnosis and Strategic Plan Jatropha spp. in México. SNICS, SINAREFI, México, 1-116.

[24] Rao, G., Sarkar, B., Raju, B., Reddy, P. and Kumar, P. (2015) Genetic Association, 
Divergence and Genotype $\times$ Environment Interaction in Jatropha (Jatropha curcas L.). Biofuels, 6, 323-329. https://doi.org/10.1080/17597269.2015.1110773

[25] Wen, Y., Tanga, M., Suna, D., Zhua, H., Weia, J., Chenb, F. and Tang, L. (2012) Influence of Climatic Factors and Soil Types on Seed Weight and Oil Content of Jatropha curcas in Guangxi, China. Procedia Environmental Sciences, 12, 439-444. https://doi.org/10.1016/j.proenv.2012.01.301

[26] Silva, L.A., Peixoto, L.A., Teodoro, P.E., Rodrigues, E.V., Laviola, B.G. and Bhering, L.L. (2017) Path Analysis and Canonical Correlations for Indirect Selection of Jatropha Genotypes with Higher Oil Yield. Genetics and Molecular Research, 16, gmr16019562. https://doi.org/10.4238/gmr16019562

[27] Laviola, B.G., Rosado, T.B., Bhering, L.L. and Kobayashi, A.K. (2010) Genetic Parameters and Variability in Physic Nut Accessions during Early Developmental Stages. Pesquisa Agropecuária Brasileira, 45, 1117-1123. https://doi.org/10.1590/S0100-204X2010001000010

[28] Steinmann, V. (2002) Diversidad y endemismo de la familia euphorbiaceae en México. Acta Botánica Mexicana, 61, 61-93.

https://doi.org/10.21829/abm61.2002.909

[29] Borah, N., Mapelli, S., Pecchia, P., Mudoi, K.D., Chaliha, B., Gogoi, A. and Aikia, S.P. (2018) Variability of Growth and Oil Characteristics of Jatropha curcas L. in Northeast India. Biofuels, 12, 1-11. https://doi.org/10.1080/17597269.2018.1472979

[30] Kambhampati, S., Aznar-Moreno, J.A., Hostetler, C., Caso, T., Bailey, S.R., Hubbard, A.H. and Allen, D.K. (2020) On the Inverse Correlation of Protein and Oil: Examining the Effects of Altered Central Carbon Metabolism on Seed Composition Using Soybean Fast Neutron Mutants. Metabolites, 10, 18. https://doi.org/10.3390/metabo10010018

[31] Wang, J., Zhou, P., Shi, X., Yang, N., Yan, L., Zhao, Q. and Guan, Y. (2019) Primary Metabolite Contents Are Correlated with Seed Protein and Oil Traits in Near-Isogenic Lines of Soybean. The Crop Journal, 7, 651-659. https://doi.org/10.1016/j.cj.2019.04.002

[32] Zhang, Y., Mulpuri, S. and Liu, A. (2015) Exogenous Glutamine Increases Lipid Accumulation in Developing Seeds of Castor Bean (Ricinus communis L.) Cultured in Vitro. Archives of Biological Sciences, 67, 1137-1149. https://doi.org/10.2298/ABS150404090Z

[33] Ustra, M.K., Silva, J.R., Ansolin, M., Balen, M., Cantelli, K., Alkimim, I.P. and Corazza, M.L. (2013) Effect of Temperature and Composition on Density, Viscosity and Thermal Conductivity of Fatty Acid Methyl Esters from Soybean, Castor and Jatropha curcas Oils. The Journal of Chemical Thermodynamics, 58, 460-466. https://doi.org/10.1016/j.jct.2012.10.007

[34] Duarte, A.B., Gomes, W.S., Nietsche, S., Pereira, M.C.T., Rodrigues, B.R.A., Ferreira, L.B. and Paixão, P. (2018) Genetic Diversity between and within Full-Sib Families of Jatropha Using ISSR Markers. Industrial Crops and Products, 124, 899-905. https://doi.org/10.1016/j.indcrop.2018.08.066

[35] Chesnokov, Y.V. and Artemyeva, A.M. (2015) Evaluation of the Measure of Polymorphism Information of Genetic Diversity. Agricultural Biology, 50, 571-578. https://doi.org/10.15389/agrobiology.2015.5.571eng

[36] Nagy, S., Poczai, P., Cernák, I., Gorji, A.M., Hegedűs, G. and Taller, J. (2012) PIC Calc: An Online Program to Calculate Polymorphic Information Content for Molecular Genetic Studies. Biochemical Genetics, 50, 670-672. https://doi.org/10.1007/s10528-012-9509-1 
[37] Serrote, C.M.L., Reiniger, L.R.S., Silva, K.B., dos Santos Rabaiolli, S.M. and Stefanel, C.M. (2020) Determining the Polymorphism Information Content of a Molecular Marker. Gene, 726, Article ID: 144175. https://doi.org/10.1016/j.gene.2019.144175

[38] Najaphy, A., Parchin, R.A. and Farshadfar, E. (2011) Evaluation of Genetic Diversity in Wheat Cultivars and Breeding Lines Using Inter Simple Sequence Repeat Markers. Biotechnology \& Biotechnological Equipment, 25, 2634-2638. https://doi.org/10.5504/BBEQ.2011.0093

[39] Morillo-Coronado, A., Gómez-Beltrán, L., Ávila-Morales, I. andrade, E. and Morillo-Coronado, Y. (2015) Caracterización molecular con microsatélites amplificados al azar (RAMs) de Inchi (Caryodendron orinocense K.). Revista Colombiana de Biotecnología, 17, 46-53. https://doi.org/10.15446/rev.colomb.biote.v17n1.50709

[40] Araújo, L.B.R., Barroso Neto, A.M., Pires, K.R.A. and Bertini, C.D.M. (2019) Genetic Diversity in the Physic Nut Based on ISSR Markers. Nativa: Pesquisas Agrárias e Ambientais, 7, 363-370. https://doi.org/10.31413/nativa.v7i4.6571

[41] Vásquez-Mayorga, M., Herrera, F. and Barboza, N. (2017) Molecular Characterization and Genetic Diversity of Jatropha curcas L. in Costa Rica. PeerJ, 5, 1-18. https://doi.org/10.7717/peerj.2931

[42] Saptadi, D., Hartati, R.S., Setiawan, A., Heliyanto, B. and Sudarsono, A. (2017) Genetic Diversity of Indonesian Physic Nut (J. curcas) Based on Molecular Marker. Agrivita, 39, 160-171. https://doi.org/10.17503/agrivita.v39i2.694

[43] Gomes, S.O., Mendes, R.F.M., Gomes, R.L.F., Veloso, M.D.C., Arriel, N.H.C., de Azevedo, D.M.P. and Lima, P.D.C. (2018) Assessment of the Genetic Diversity and Population Structure of Jatropha curcas Accessions in Brazil Using ISSR Markers. Genetics and Molecular Research: GMR, 17, 18208. https://doi.org/10.4238/gmr18208

[44] Li, H., Tsuchimoto, S., Harada, K., Yamasaki, M., Sakai, H., Wada, N. and Fukui, K. (2017) Genetic Tracing of Jatropha curcas L. from Its Mesoamerican Origin to the World. Frontiers in Plant Science, 8, 1539. https://doi.org/10.3389/fpls.2017.01539

[45] Aguilera-Cauich, E., Pérez-Brito, A., Navarrete, G., López-Puc, G., Najera, J., Sacramento, C., Rubio, A., Uc-Várguez, A., Góngora-Canul, C. and Mijangos-Cortes, J. (2015) Assessment of Phenotypic Diversity and Agronomic Contrast in American Accessions of Jatropha curcas L. Industrial Crops and Products, 77, 1001-1003. https://doi.org/10.1016/j.indcrop.2015.09.063

[46] Avendaño, R., Díaz, E.G., Valdez-Melara, M., Solano, N.C., Villalobos, A.M., Cascante, F.A., Benavides, B.W. and Solís-Ramos, L.Y. (2015) Genetic Diversity Analysis of Jatropha Species from Costa Rica Using AFLP Markers. American Journal of Plant Sciences, 6, 2426-2438. https://doi.org/10.4236/ajps.2015.614245

[47] Patil, P.G., Singh, N.V., Parashuram, S., Bohra, A., Sowjanya, R., Gaikwad, N. and Babu, K.D. (2020) Genome-Wide Characterization and Development of Simple Sequence Repeat Markers for Genetic Studies in Pomegranate (Punica granatum L.). Trees, 34, 987-998. https://doi.org/10.1007/s00468-020-01975-y 